\title{
A ROLE OF SOCIAL NETWORKS IN CREATING A MARKETING CONCEPT OF HOTEL COMPANIES
}

\author{
Filip Đoković, \\ Ivana Damnjanović, \\ Vladimir Džamić
}

Singidunum University, Faculty of business in Valjevo, Valjevo, Serbia

Correspondence:

Filip Đoković

e-mail:

fdjokovic@singidunum.ac.rs

\begin{abstract}
:
The last decade has witnessed turbulent changes in hotel industry marketing. Key reasons arise from high elasticity of demand and the volume of information about the destination and accommodation available to potential guests. Hotels need repositioning in the market and one possible path requires radical alteration of marketing concept in terms of adapting to new methods of communication with guests. In addition to website as the main communication channel within the framework of information and communication technologies, social networks are becoming increasingly present. Numerous social networks are characterized by a specific way of communication. Therefore, a role of marketing in hotel sector is being well acquainted with diversified and abundant functions of various social networks and characteristics of their users.
\end{abstract}

Key words:

marketing, social networks, hotel industry.

\section{INTRODUCTION}

The environment in which hotel companies operate is very turbulent due to many changes that permeate every business sector. Any change is characterized by speed and scope of impact. Information technologies have contributed to the acceleration of change which cannot be seen in its entirety, and to the fact that it is actually up to the hotel management to shape the policies and strategies in order to create a flexible organization.

The changes are characterised by uncertainty and in some ways can be perceived as a "strike" on the current operations and results in general. Therefore, the creation of flexible organizations is essential so the changes in modern hospitality market trends could be implemented in the relevant business operations.

Relations between hotel and market, taking into account the nature of the change, have become more complex for a number of reasons. Firstly, marketing concept changes radically depending on information technology. The focus has evolved from a product to the consumer/ customer, or the requirements and the ways in which guests express their demands have changed and are changing. Secondly, communication channels are becoming more numerous and each new communication channel requires a specific mode of communication. Thirdly, segmentation of target group gets new frames due to the development of information and communication technologies. There are new segments and target groups that must be duly recognized by decision-makers in hotels. 


\section{MARKETING CONCEPT OF HOTEL COMPANIES}

Marketing concept of hotel and other businesses indicates a market-oriented thinking (Djokovic, F., 2013). The key question is how to determine the manner in which to market a hotel product? Acceleration of the flow of information, taking into account its quality, scope and potential impact, has led to an essential systematic approach in creation of marketing concept.

The aim of any hotel company is making profit, which is a result of meeting its guests' needs. Hotel as a bearer of product consists of parts that have to be complementary: location, hotel facilities, service range, price and brand. Only realistic assessment of accommodation, IT and human resources can provide the basis for creating marketing concept.

In order to make the long term results, marketing concept must have a strategic nature. This means that hotel management is committed to determining target groups and adapting to their needs in a systematic manner by careful monitoring and predicting changes in their behaviour (Grgona, J., Supić, A., 2007).

Formulation of marketing concept must have the purpose of considering all processes and phenomena in hotel operations. Strategic framework of marketing concept requires excellent knowledge of value chain.

Profit as a strategic direction is a result of the primary and supporting activities in the hotel. Primary activities relate to all phases in which the customer is in focus (phase prior to arrival, the phase when the customer resides and the phase in which the guests have left the hotel).

Supporting activities are activities that are not strictly related to the service but create the setting for quality service delivery. These are the sectors of finance, procurement, human resources and others. Excellent knowledge of primary and supporting activities represents the basis for creating marketing concept the purpose of which is meeting hotel's strategic and operational objectives.

Modern trends in tourism and corresponding hotel market, impose different views on the market itself and ways of communication. Information technologies have created an environment in which approaches to the market are radically changing. Since the impact of information and communication technology is dominant, so-called e-marketing can be discussed.

Defining e-marketing in the hotel industry is diverse, mainly due to the various aspects of perception. Some authors believe that the Internet is at the core of e-marketing, assuming certain applications and information and communication technologies solutions. There is a perception that e-marketing is oriented exclusively to sales and promotional activities via the Internet. There is also the opinion that e-marketing includes Internet marketing and therefore has a wider scope as it involves a number of communication technologies (Knežević, M., 2016).

Social networks fall within the domain of e-marketing and increasingly influence the creation of hotel marketing concept. The essence of social networks is to attract potential guests to stay at hotel and to surpass their expectations to become part of the loyalty program. In last decade, the number of social networks has grown rapidly, so it is important to take into account the specific characteristics of each of them.

\section{ROLE OF SOCIAL NETWORKS IN HOTELS OPERATIONS}

Social networks are a part of social media. In certain cases, these terms are synonymous. Being active on a social network means having a profile that contains specific information about the user. It is noteworthy, particularly from corporate perspective, that social network user (e.g. hotel) can fully coordinate activities related to the content on social networks. Each content is also possible to be commented on by a variety of content (Štavljanin, V., Filipovic, V., Kostić Stanković, M., 2011).

When planning a trip, regardless of whether they travel for recreation and leisure or business, tourists find information about destination on the Internet. This also applies to the accommodation. The Internet as a source of information for potential guests is essential because it provides an opportunity for diversity of content which allows examination of destination, accommodation and associated facilities from multiple perspectives. Social networks in this case represent virtual frames in which information according to specific requirements can be found. The reason is that a growing number of potential tourists are active on social networks.

The virtual frames or so-called profiles on social networks represent a huge potential given the diversity of content. The biggest hotel chains such as IGH and Marriot have recognized the importance of social networks. They have realised that their use contributes to a better understanding of target groups, strengthening the brand and ultimately achieving higher profits. In addition to the hotel, the importance of social networks has also been recognized by tour operators and travel agencies, airlines, tourism organizations and other enterprises in the field of tourism.

Certainly the most important aspect is that social networks are recognized as one of the key means of communication with the market, although, it carries certain risks (Loncaric, D., Melissa, N., 2015). It is necessary to 
manage social networks adequately in order to achieve marketing objectives (Iacianci, C., 2015). The point is that social networks are means of communication, not an end. The focus on social networks as a communication tool implies excellent knowledge of general and specific characteristics of each social network in order to avoid undesirable effects (dissatisfaction, lower capacity utilization, different message due maintenance of certain events, etc.).

One of the key benefits of social networks is that on the basis of excellent knowledge of a particular network target group can be efficiently defined. Based on search criteria, each segment is easily determined and thus a communication plan made. Each activity within marketing concept, especially old, requires certain costs (Unković, S., Zecevic, B., 2011). The Internet as a virtual space framed in a social network initiates significantly lower costs in the marketing budget.

Finally, the use of social networks includes control mechanisms. This means that activities undertaken on social networks can be controlled through specific tools, e.g., via Google analytics information on how much specific content is visited, how much time potential guests spend on them, the extent to which content is explored and the like can be reached.

During the formation of the first social networks, users exploited them primarily for private purposes. However, the corporatisation of social networks has become an imperative in the last decade. Use of profiles for private purposes (maintaining contact with friends, family, etc.) is significantly different from corporate (brand improvement, increasing loyalty, etc.).

A new hotel marketing concept involves two-way communication. This means that the initiation of any content by hotel is under the scrutiny of the virtual public (potential guests, competition, etc.). For each content reactions can be expected (comments, suggestions, proposals, etc.).

\section{BASIC FEATURES OF SOCIAL NETWORKS USED IN HOTEL BUSINESS}

The process of transition from private to business purpose of social networks was fast and it was an immense change which resulted in review of the previous marketing activities. In hotel industry it has caused so-called domino effect, in the sense that the initiators were big corporate hotel chains. Then it spilled over to other corporate and voluntary hotel chains and independent hotels.

The most significant social networks used in hotel business today are:

- Facebook;

- Instagram;
- Twitter;

- Pinterest;

- Foursquare;

- Tripadvisor;

- Google plus;

- Linkedin.

Each social network has its own characteristics which affect the diversification of users. Each specificity points to creation and delivery of content sent as well as control of effects of the activities undertaken. What is true for one social network is often unacceptable to the other and may cause undesired effects.

Use of profiles or accounts on social networks in hospitality requires the involvement of qualified human resources. Bearing in mind the fact that these jobs are novel in the last decade, willingness and understanding of management to perceive the importance of the use of social networks and employment of professional people need to be emphasized.

\begin{tabular}{|c|c|c|}
\hline \multirow{2}{*}{$\begin{array}{c}\text { social } \\
\text { network }\end{array}$} & \multicolumn{2}{|c|}{ Features } \\
\hline & Content & Specificity \\
\hline Facebook & $\begin{array}{l}\text { Text, photos, audio } \\
\text { and video recordings }\end{array}$ & $\begin{array}{l}\text { Dominant entertain- } \\
\text { ment facilities }\end{array}$ \\
\hline Instagram & $\begin{array}{l}\text { Photos, audio and } \\
\text { short video clips }\end{array}$ & $\begin{array}{l}\text { Content is only sent } \\
\text { to the mobile phone, } \\
\text { tablet, hashtags }\end{array}$ \\
\hline Twitter & Text, photography & $\begin{array}{l}\text { Limitations of } \\
\text { characters, a focus } \\
\text { on information, } \\
\text { hashtags }\end{array}$ \\
\hline Pinterest & Photos and pictures & Focus on visuals \\
\hline Foursquare & Displaying locations & $\begin{array}{l}\text { The focus on the } \\
\text { location and charac- } \\
\text { teristics of the site, } \\
\text { for example. the ho- } \\
\text { tel and its facilities }\end{array}$ \\
\hline Google plus & $\begin{array}{l}\text { The possibility of } \\
\text { more extensive texts, } \\
\text { photographs, record- } \\
\text { ings }\end{array}$ & Circles by interests \\
\hline Tripdvisor & Text, photography & $\begin{array}{l}\text { Rating and com- } \\
\text { menting hotel - } \\
\text { Review }\end{array}$ \\
\hline Linkedin & $\begin{array}{l}\text { Information on the } \\
\text { business career of } \\
\text { individuals and en- } \\
\text { terprises - timeline of } \\
\text { career, tables, charts, } \\
\text { biographies, photos }\end{array}$ & Business purpose \\
\hline
\end{tabular}

Table 1. Features of social networks 
The table shows the main characteristics of social networks that are commonly used in the hotel industry. It should be noted that the presence on most social networks is effective only if the hotel is familiar with their users. Also, the activities on social networks must be in line with hotel strategic orientation to promote the brand and increase market share.

The control functions of social networks indicate the need for constant evaluation of the undertaken business activities. Therefore, it is important that social networks are an integral part of the objectives, plans, policies and procedures of hotel operations.

Social networks should be key in the process of potential travellers' search and decision-making to stay at a particular hotel. Website as hotel's important presentation continues to be a glorious picture of the hotel, which is very often not in line with the actual situation. Therefore, the role of social networks is to compensate for deficiencies of the site.

In the chain of decision-making on the selection of accommodation, social networks precede the Internet distribution systems. Internet distribution systems as technology enable users to obtain information and organize their trips entirely. The role of social networks influences the final choice of the mode of transport and accommodation facility.

Connection between the Internet distribution systems and social networks is important in order to maximize the accommodation utilization in short term and thus achieve financial targets.

The essence of the use of social networks is additional information on destinations, accommodations and other amenities. Apart from additional information, it is important to note that through social networks information found on the official websites of the hotel and tour operators can be confirmed or proved. Depending on the social network, information confirmation and additional information can be sublimated through a variety of content such as video clips, short messages (eg. Tweets), photos etc. Acknowledging reviews (Tripadvisor), a potential customer can change the original decision on booking a stay at a hotel.

A special, though no less important segment, is the guest stay in the hotel. Surpassed expectations can initiate guest's expression of satisfaction with a timely photograph or image on a social network (e.g. Instagram). Also, dissatisfaction with service may result in display of revolt through certain content (photos, comments, etc.). Any deviation, enthusiasm or anger can be expressed on social networks.
Simultaneous provision and consumption of services means that the quality of service or overall experience at the hotel is assessed at the moment. Therefore, any delay in finding solutions to problems can adversely affect immediately after the provision of services.

Customer loyalty is also built after he/she leaves the hotel. This is particularly important for tourists who stayed at a hotel for the purpose of recreation and rest. The phase of guest adaptation to ordinary activities lasts for a certain period of time during which the impressions of the stay at the hotel are sorted according to their level of satisfaction. This means that after staying at a hotel, guest transfers the experience of the trip, including the hotel stay, through photos, videos and other content.

The tasks of marketing and sales staff need to be diverse and interrelated and include the following:

- Setting objectives for hotel e-marketing;

- Creating unique content appropriate for a particular social network (e.g. indigenous hashtag);

- Control and monitoring of broadcast content and comparison with the defined operational and strategic goals;

- Continuous coordination with other sectors, so that employees in marketing and sales are timely informed;

- Conformity of the hotel content across social networks;

- The introduction of innovations in the presentation of certain content;

- Reports to management about the effects of the use of social networks and other information that may be relevant to the decision-making.

Stages of informing potential guests during the stay in the hotel, transportation phase and the phase after leaving the hotel are supported by numerous activities on social networks. It is, therefore, important that employees in marketing and sales closely monitor and act in accordance with business policies (e.g. especially in the case of lower hotel occupancy).

\section{CONCLUSION}

The marketing concept represents the basis for creating the marketing mix, marketing strategies and strategic objectives. Social networks in these settings play an important role as a mediator and controller of numerous activities and relationships between the hotel and the market.

There is no doubt that the presence of hotels on social networks is inevitable, and that information and commu- 
nication technologies have contributed to reassessment of marketing concepts up to the moment. The objectives of hotel company operations have not changed. However, marketing channels which also have a role in achieving these goals have altered. Achieving profits, improving brand as well as permanent control of operations now have an additional component which valorises achieved results more quickly, efficiently and effectively.

Through the presence on social networks, hotel meets its guests further and discovers its potential target groups. In the long term, time is more effectively managed and management obtains information that may affect the creation of marketing concepts more quickly.

Orientation towards e-marketing requires employees with professional knowledge, skills and abilities which will bring a hotel closer to its market. In addition to hotel staff, the tendency is to outsource the activities within e-marketing and submit them to specialized marketing agencies that have experience in so-called "digital".

Good knowledge of social networks entails analyzing each one so a decision which social network to use as a communication channel can be made. Taking into account the specificity of each social network, the decision on the use of certain but not all can have enormous significance for the promotion of the brand, increasing capacity utilization and loyalty of the guests.

\section{REFERENCES}

Đoković, F. (2013). Poslovno odlučivanje o marketing koncepciji u hotelskom preduzeću. Poslovne studije - časopis za poslovnu teoriju i praksu, 5(9-10), 230213. doi:10.7251/POS1310229J

Grgona, J., Supić, A. (2007) Uloga marketinške koncepcije u hotelskom poslovanju. Ekonomska praksa $i$ misao, 1, 48-49. UDK 339.138(640.4)

Iacianci, C. (2015) Hotel manager's attitudes toward social media. Disertacija. Kent State University College of Education, Health, and Human Services, 18-19.

Knežević, M. (2016) Uticaj Internet distributivnih sistema i društvenih mreža na promociju, prodaju i kvalitet usluga hotela sa 4 i 5 zvezdica. Disertacija. Univerzitet Singidunum, 34-36.

Lončarić, D., Radetić, N. (2015) The implementation of e-marketing in the hotel industry: the case of Istria county. Zbornik Veleučilišta u Rijeci, 1, 16-17. UDK 658.8:640.4:004.773

Štavljanin, V., Filipović, V., \& Kostić-Stanković, M. (2011) Social Media in Marketing and PR. JITAJournal of Information Technology and Applications, 2(2), 113-118. UDK 32.019.5:658.8

Unković, S., Zečević, B. (2011) Ekonomika turizma, CID Ekonomskog fakulteta, Beograd, str. 125-127. 